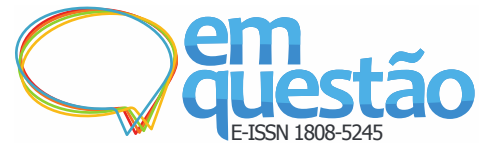

\section{Apresentação da seção especial}

Os artigos apresentados na Seção Especial, da revista Em Questão, sobre o tema "Patrimônio Cultural, hegemonia e mediações sociais na América Latina: agendas de investigação e novos cenários para o século XXI” são resultados de alguns trabalhos apresentados no XVI Congresso de Antropologia, na Colômbia, e no V Congresso Associação Latino-americana de Antropologia, realizado entre 6 a 9 de junho de 2017, na Pontifícia Universidade Javeriana, na cidade de Bogotá, na Colômbia.

O objetivo dessa Seção Especial é apresentar um conjunto de casos e experiências recentes de patrimonialização na América Latina. A abordagem proposta afasta-se dos olhares tecnocráticos e instrumentais que neutralizam as relações assimétricas de poder que, regularmente, se criam com os processos que se "colocam valor" e intervenções patrimoniais. Nesse sentido, entendemos que os valores e significados associados ao patrimônio não são homogêneos, já que se definem a partir de múltiplas inscrições e ou agendas reinterpretações do passado que competem por legitimar-se dentro das estruturas, relações de poder e tecnologias de classificação. Por outro lado, o patrimônio cultural e os processos de patrimonialização são cenários de disputas e diferenciação complexos. Assim, o campo patrimonial amplia-se e supera o Estado, suas instituições, seus aparatos normativos e marcos jurídicos, a fim de inserir-se em dinâmicas complexas de apropriação, recreação e configuração do que se concebe como patrimônio. Esse marco resulta importante debate, também, sobre a instrumentalização política que os diferentes níveis dos Estados Nacionais podem fazer com aquilo que se considera patrimônio, bem como a relação complexa entre gestão patrimonial e participação local. Não obstante, buscamos explorar e problematizar as intersecções entre práticas sociais, discursos e políticas patrimoniais na América Latina.

Expressamos nossos sinceros agradecimentos à profa. Dra. Samile Andréa de Souza Vanz, editora-chefe da revista Em Questão, pela sensibilidade, acolhida e pela disponibilização do espaço para divulgação dos estudos 


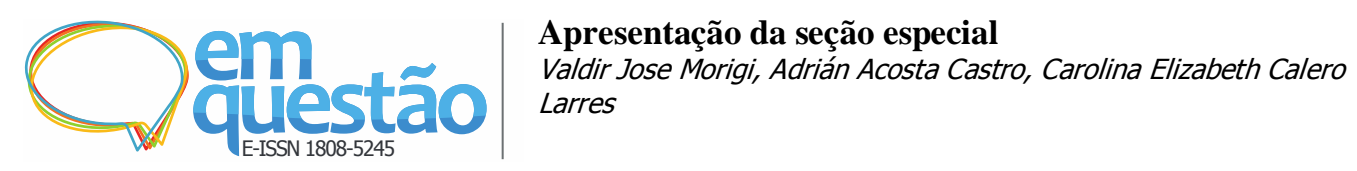

realizados sobre o tema abordado na Seção Especial. Ainda, à bibliotecária Natascha Helena Franz Hoppen, ao Luis Fernando H. Massoni, doutorando do Programa de Pós-graduação em Comunicação e Informação (PPGCOM), e ao Natan Fritscher Kussler, mestrando do PPGCOM, que realizaram as revisões das normas e a Micaele Zagonel Picolli, responsável pela editoração eletrônica. Por fim, agradecemos, especialmente, à profa. Dra. María Estela Guevara Zárraga, a quem convidamos para introduzir os trabalhos dessa seção e todos os autores que enviaram seus artigos para compor a seção.

A todos, desejamos uma boa leitura!

Os Organizadores: Valdir Jose Morigi, Adrián Acosta Castro, Carolina Elizabeth Calero Larrea 